\title{
A sensitive environmental DNA (eDNA) assay leads to new insights on Ruffe (Gymnocephalus cernua) spread in North America
}

\author{
Andrew J. Tucker • W. Lindsay Chadderton • Christopher L. Jerde • \\ Mark A. Renshaw $\cdot$ Karen Uy • Crysta Gantz - Andrew R. Mahon • \\ Anjanette Bowen · Timothy Strakosh · Jonathan M. Bossenbroek • \\ Jennifer L. Sieracki · Dmitry Beletsky • Jennifer Bergner • \\ David M. Lodge
}

Received: 7 July 2015/ Accepted: 27 June 2016/Published online: 6 July 2016

(C) The Author(s) 2016. This article is published with open access at Springerlink.com

\begin{abstract}
Detection of invasive species before or soon after they establish in novel environments is critical to prevent widespread ecological and economic impacts. Environmental DNA (eDNA) surveillance and monitoring is an approach to improve early detection efforts. Here we describe a large-scale conservation application of a quantitative polymerase chain reaction assay with a case study for surveillance of a federally listed nuisance species (Ruffe, Gymnocephalus cernua) in the Laurentian Great Lakes. Using current Ruffe distribution data and predictions of future Ruffe spread derived from a recently developed model of ballast-mediated dispersal in US waters of
\end{abstract}

\section{A. J. Tucker $(\bowtie) \cdot$ W. L. Chadderton}

The Nature Conservancy, 1400 E. Angela Blvd, Unit \#117, South Bend, IN 46617, USA

e-mail: atucker@tnc.org

C. L. Jerde - D. M. Lodge

Department of Biological Sciences, Environmental Change Initiative, University of Notre Dame, 100 Galvin Life Sciences Center, Notre Dame, IN 46556, USA

M. A. Renshaw · K. Uy · C. Gantz

Department of Biological Sciences, University of Notre Dame, 100 Galvin Life Sciences Center, Notre Dame, IN 46556, USA

\section{A. R. Mahon · J. Bergner}

Department of Biology, Institute for Great Lakes Research, Central Michigan University, Mount Pleasant, MI 48859, USA the Great Lakes, we designed an eDNA surveillance study to target Ruffe at the putative leading edge of the invasion. We report a much more advanced invasion front for Ruffe than has been indicated by conventional surveillance methods and we quantify rates of false negative detections (i.e. failure to detect DNA when it is present in a sample). Our results highlight the important role of eDNA surveillance as a sensitive tool to improve early detection efforts for aquatic invasive species and draw attention to the need for an improved understanding of detection errors. Based on axes that reflect the weight of eDNA evidence of species presence and the likelihood of secondary

\footnotetext{
A. Bowen

U.S. Fish and Wildlife Service, 480 W. Fletcher Street, Alpena, MI 49707, USA

T. Strakosh

Green Bay Fish and Wildlife Conservation Office, 2661

Scott Tower Drive, New Franken, WI 54229, USA

J. M. Bossenbroek · J. L. Sieracki

Department of Environmental Sciences, Lake Erie Center, University of Toledo, Oregon, $\mathrm{OH} 43616$, USA

D. Beletsky

Cooperative Institute for Limnology and Ecosystems Research, School of Natural Resources and Environment, University of Michigan, 4840 S. State Rd., Ann Arbor, MI 48108, USA
} 
spread, we suggest a two-dimensional conceptual model that management agencies might find useful in considering responses to eDNA detections.

Keywords Quantitative polymerase chain reaction $(\mathrm{qPCR}) \cdot$ Aquatic invasive species (AIS) .

Surveillance $\cdot$ Early detection

\section{Introduction}

The characteristic lag time between introduction and widespread establishment of biological invaders provides a window of opportunity for early detection and eradication of potentially harmful species in novel environments (Myers et al. 2000; Crooks 2005; Lodge et al. 2006; Mehta et al. 2007). Environmental DNA (eDNA) surveillance is a method for improving early detection efforts for rare aquatic species, including harmful species at the leading edge of an invasion front (reviewed by Rees et al. 2014). Environmental DNA (eDNA) surveillance is especially well suited for aquatic environments because cells and sloughed tissues are suspended in water and can be collected and screened to detect DNA of target organisms that are present but difficult to detect with conventional surveillance tools (Goldberg et al. 2011; Jerde et al. 2011; Sweeney et al. 2011; Dejean et al. 2012; Pilliod et al. 2013; Takahara et al. 2013; Jane 2014). Early applications of eDNA for aquatic invasive species (AIS) surveillance utilized a traditional endpoint polymerase chain reaction (PCR) approach, but eDNA methods are rapidly evolving and recent advances in the development of quantitative PCR (qPCR) assays for sample screening highlight the potential for improved sensitivity of eDNA based surveillance (Beja-Pereira et al. 2009; Bott et al. 2010; Thomsen et al. 2012a, b; Wilcox et al. 2013; Nathan et al. 2014; Turner et al. 2014a, b). Here we describe the application of a qPCR screening assay with a case study for surveillance of Ruffe, a federally designated 'nuisance species,' across the Laurentian Great Lakes (Nonindigenous Aquatic Nuisance Prevention and Control Act of 1990, Public Law 101-646).

Ruffe, a percid fish native to western and northern Europe, was first observed in North America in the St. Louis River (the westernmost tributary of Lake Superior) in 1986 (Pratt 1988), having likely been introduced via ballast water of vessel(s) originating from a port associated with the Elbe River drainage (Stepien et al. 2005). A rapidly reproducing population of Ruffe in the St. Louis River, combined with declines in some native fish populations and a persistent eastward advance, led the Aquatic Nuisance Species Task Force, under the authority of the Nonindigenous Aquatic Nuisance Prevention and Control Act, to declare Ruffe a 'nuisance species' in the spring of 1992. This designation triggered formal surveillance efforts by the US Fish and Wildlife Service (USFWS) and the Ontario Ministry of Natural Resources to detect pioneering populations of Ruffe in the Great Lakes. Ruffe is now known to inhabit many tributaries along the US shoreline of Lake Superior, from Duluth, Minnesota to the Tahquamenon River, Michigan. Range expansion into Lake Huron and northern Lake Michigan has also been documented and is presumed to have occurred as the result of larval fish transport in the ballast water of bulk carrier vessels traveling from invaded ports in Lake Superior or abroad (Bowen and Keppner 2013). The most recent USFWS surveillance reports indicated presence of Ruffe in the Cheboygan River (Cheboygan, MI, Lake Huron) and in Green Bay (near Escanaba, MI and Marinette, WI, Lake Michigan; Bowen and Keppner 2013). To date, live Ruffe have not been observed in Lake Erie or the southern basin of Lake Michigan, where it could potentially bridge the hydrological divide that separated the Great Lakes basin from the Mississippi River basin before the construction of the Chicago Sanitary and Ship Canal (US Army Corps of Engineers 2014).

Using current Ruffe distribution data from USFWS and the US Geological Survey Nonindigenous Aquatic Species database (USGS-NAS; http://nas.er.usgs.gov/ default.aspx), along with predictions of future Ruffe distribution derived from a recently developed model of ballast-mediated Ruffe dispersal in the US waters of the Great Lakes (Sieracki et al. 2014), we designed an eDNA surveillance study to target Ruffe at the putative leading edge of the invasion. The main objectives of our surveillance effort were to: (1) monitor invasion of high-risk ballast uptake ports in the upper Great Lakes that could seed Lake Erie or the southern basin of Lake Michigan; (2) assess spread of Ruffe in eastern Lake Superior and in the northern parts of lakes Michigan and Huron; and, (3) search for potential incursions of Ruffe in Lake Erie and southern Lake Michigan. Our findings suggest a far more advanced 
invasion front for Ruffe in the Great Lakes than has been documented using the conventional fisheries methods employed for formal Ruffe surveillance efforts. We propose a conceptual framework to facilitate application of our results for the management of Ruffe, based on axes that reflect the weight of eDNA evidence of species presence and the likelihood of secondary spread.

\section{Methods}

Marker development

Molecular markers for G. cernua were designed using publically available sequence information (GenBank, www.ncbi.nlm.nih.gov). We assembled sequences for 23 Percidae species ( 22 of which are historically found in the Great Lakes basin plus Ruffe) for the cytochrome b, cytochrome $\mathrm{c}$ oxidase subunit 1 (COI), and control region as these regions of the mitochondrial genome were best represented in GenBank for the taxa of interest. Three COI primer pairs and two primer pairs from the control region were evaluated with tissue-extracted DNA from G. cernua and 17 of the cooccuring Great Lakes Percidae species. DNA extractions were all normalized to $1 \mathrm{ng} / \mu \mathrm{L}$ and tested under the qPCR conditions described below (see $q P C R$ amplification and evaluation). Amplifications were post-PCR cleaned with ExoSAP-IT (USB) and submitted to the Genomics and Bioinformatics Core Facility at the University of Notre Dame (GBCF) for unidirectional Sanger Sequencing. Sequences were visually inspected with Sequencher ${ }^{\mathrm{TM}}$ (GeneCodes) and submitted to BLAST on NCBI. The optimal pair of primers, Ruffe_COI_Fa (5'-TACCCTCCCCTATC AGGAAACTT-3') and Ruffe_COI_Ra (5'-TAATTG CGCCCAAGATTGAGGAGAT-3'), targeted a 111 bp fragment of the COI.

DNA extracted from tissues of several nontarget taxa (Etheostoma caeruleum, E. blennoides, E. zonale, Percina caprodes, and $P$. copelandi) produced amplicons that were identified as G. cеrnua by Sanger sequencing. As the tissue samples were provided by a museum collection, the potential for contaminating DNA (G. сеrnua) in the samples seemed plausible and the ability of the assay to identify the trace contaminant DNA in an environment dominated by the DNA of the non-target taxon added support for the stringent application of the assay on eDNA samples. Additional details for the design and validation of the assay are given in "Appendix 1: Detailed description of methods for qPCR marker development" section.

Sample collection, filtration, and extraction

From October 25, 2012 to September 11, 2013, we collected 1289 2-L water samples from 24 discrete locations in the Great Lakes basin (Fig. 1). We focused our sampling efforts on 'high-risk' locations at the leading edge of the known Ruffe invasion front (e.g. eastern Lake Superior, northern Lake Huron from Alpena to the Cheboygan River, and Green Bay) and on sites receiving the largest volume of shipping traffic from Ruffe infested ports within the US waters of the Great Lakes (e.g. Chicago, IL and Toledo, OH; National Ballast Information Clearinghouse 2014). Surface-water samples were collected in autoclaved 2-L Nalgene bottles ( $45 \mathrm{~min}$ at $121{ }^{\circ} \mathrm{C}$ ). Subsurface water samples were collected within one meter of the bottom with a Van Dorn sampler (2.2 L opaque PVC; Wildlife Supply Co., Yulee, FL) or Kemmerer sampler (2.2 L acrylic; Wildlife Supply Co., Yulee, FL) and transferred in the field to autoclaved 2-L Nalgene bottles. All sample locations were geographically referenced with GPS (Garmin Dakota 10; s.e., $<10 \mathrm{~m}$ ). Samples were filtered and extracted as recommended by Mahon et al. (2010). Briefly, samples were vacuum filtered onto $1.5 \mu \mathrm{m}$ pore-size glass fiber filters within $24 \mathrm{~h}$ of collection, filter papers were stored at $-20{ }^{\circ} \mathrm{C}$, and DNA was extracted with the PowerWater DNA Isolation kit (MO-Bio Laboratories Inc., Carlsbad, CA).

Apart from the 2-L Nalgene bottles, which were autoclaved as described above, all equipment used in the sampling and screening effort, including boats, was sterilized with a $10 \%$ bleach solution or sourced directly from suppliers (e.g. latex gloves). Cooler blanks, a single 2-L bottle filled with deionized water, were placed in each sample cooler and taken into the field. The cooler blanks were opened in the field, resealed, and then submerged into the waterbody being sampled. Prior to filtering each sample, approximately $500 \mathrm{~mL}$ of deionized water was passed through each sterilized filter apparatus onto a filter paper to test for contamination on lab equipment; these samples are referred to as equipment controls. All cooler blanks were screened for contamination and, 


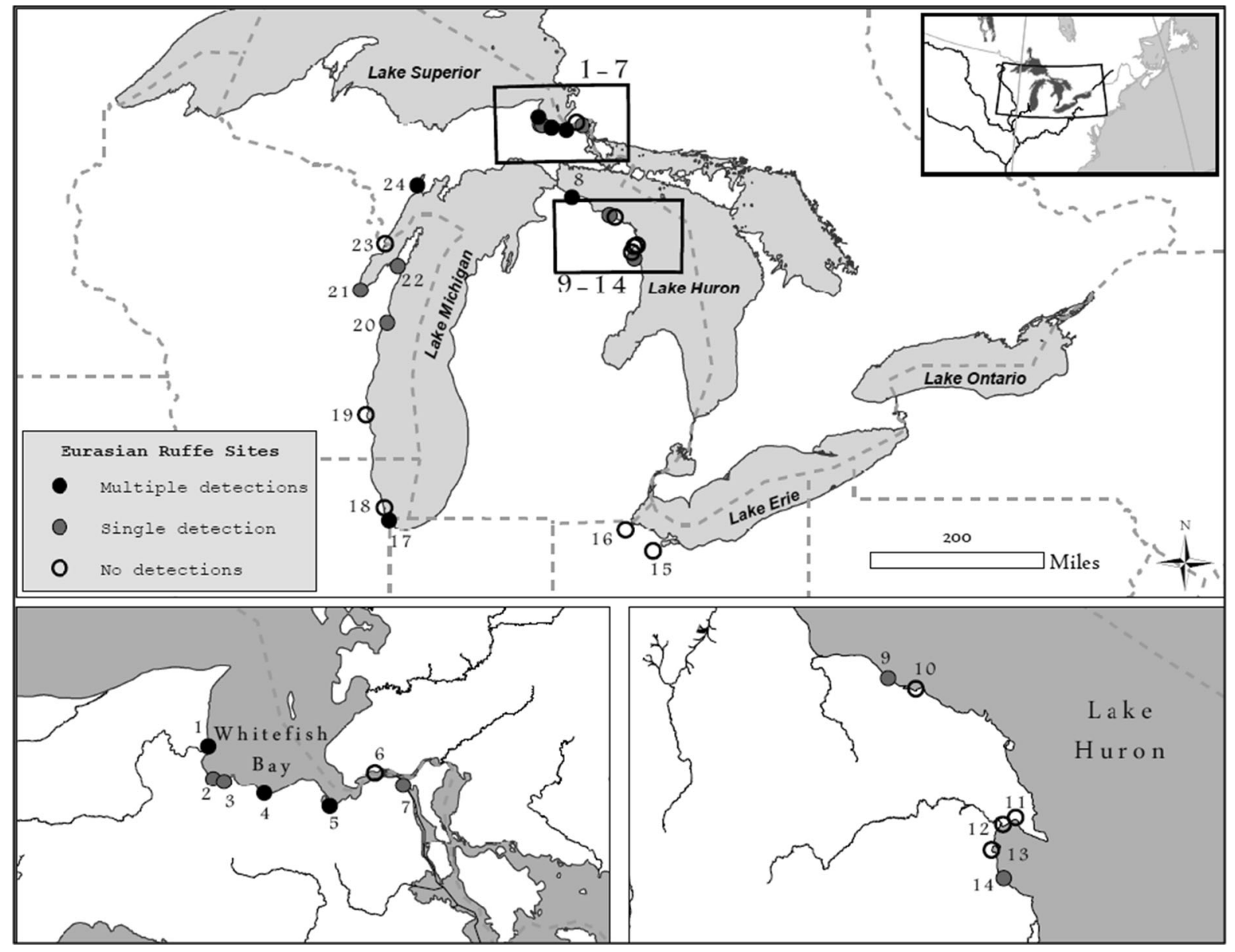

Fig. 1 Sampling locations for 2012-2013 Ruffe eDNA surveillance effort

for every field sample that tested positive, the corresponding equipment control was processed.

qPCR amplification and evaluation

qPCR amplifications were conducted using a SYBR ${ }^{\circledR}$ Green I dye assay. The qPCR amplification cocktail consisted of $1 \mathrm{X}$ Power $\mathrm{SYBR}^{\circledR}$ Green Master Mix (Life Technologies), $300 \mathrm{nM}$ of each primer, $0.4 \mu \mathrm{g} /$ $\mu \mathrm{L}$ of Bovine Serum Albumin (Ambion), and $4 \mu \mathrm{L}$ of extracted DNA in a $20 \mu \mathrm{L}$ reaction. We performed all reactions on an Eppendorf Mastercycler ep realplex 2 thermocycler. Thermal cycling conditions were as follows: an initial activation step at $95{ }^{\circ} \mathrm{C}$ for $10 \mathrm{~min}$; 40 cycles of $95{ }^{\circ} \mathrm{C}$ for $15 \mathrm{~s}$ followed by $60^{\circ} \mathrm{C}$ for $1 \mathrm{~min}$; and, a melting curve analysis transitioning from 60 to $95{ }^{\circ} \mathrm{C}$ over $20 \mathrm{~min}$. The fluorescence threshold for each plate was automatically determined by the Eppendorf realplex software using the default Noiseband setting. The fluorescence baseline was calculated for every reaction individually using the default Automatic Baseline setting of the Eppendorf realplex software.

Each eDNA extract was run in triplicate with a single positive control (tissue-derived DNA) and single negative control (1X TE buffer, low EDTA) included on each qPCR plate. Every amplification profile and melt curve profile was visually examined to confirm exponential amplification and a melting temperature matching that of tissue derived reactions. Successful amplifications were post-PCR cleaned with ExoSAP-IT (USB) and submitted to the GBCF for unidirectional Sanger Sequencing. Sequences were checked visually with 4 Peaks (http://nucleobytes. 
com/index.php/4peaks) or Sequencher ${ }^{\mathrm{TM}}$ (GeneCodes) and specificity to Ruffe was verified by BLAST on NCBI. eDNA extracts were considered positive for the presence of Ruffe DNA only after successful amplification and successful sequence confirmation. Final confirmation for a positive sample required a negative result from the corresponding equipment control.

Assessment of failure to detect target DNA

To assess to what extent our sample screening protocol (i.e. eDNA extract run in triplicate) failed to detect target species DNA when it was present in a sample, we screened samples collected in 2013 a second time. All samples that tested negative in the first round of screening were re-assayed in sextuplet (i.e. 6 technical qPCR replicates) with the appropriate controls in place as in previous analyses. As before, successful amplifications were post-PCR cleaned and submitted for unidirectional Sanger sequencing and equipment controls were screened for final confirmation of a positive DNA detection.

\section{Results}

A total of 72 samples across fourteen locations tested positive for Ruffe DNA (Fig. 1). All positive detections were from samples collected over the period May to July 2013 (Table 1). The majority of positive detections $(>80 \%$ ) were from surface-water samples, however, a larger proportion of total subsurface samples $\quad(\sim 14 \%$; average depth $=3.4 \mathrm{~m}$, $\min =2 \mathrm{~m}, \max =5 \mathrm{~m})$ resulted in positive detections as compared to surface-water samples $(\sim 5 \%$; Table 1). One of the positive detections was a cooler blank from a collection at Escanaba, Michigan in May 2013. Although three other samples tested positive from the May 2013 sampling event at Escanaba, none of these additional positive samples were associated with the contaminated cooler blank (i.e. the three positive samples were not in the same cooler). Because no other samples associated with the contaminated cooler blank tested positive for Ruffe DNA, we did not discard any data.

Positive eDNA detections at the Cheboygan River and Escanaba River corroborate results from conventional fisheries surveillance efforts where at least one
Ruffe has been captured at each of these locations over the same time period (Table 2). Ruffe DNA was also detected at seven additional locations where conventional sampling failed to capture live Ruffe in 2012 and 2013, although, at two of these locations, Ruffe have been captured in previous years (site 1 starting in 2006 and site 9 in 2008). Positive detections also occurred from five locations for which conventional surveillance for Ruffe (or with gear capable of incidentally capturing Ruffe) has not been reported. There were no instances where Ruffe were captured using conventional methods in 2012 or 2013 and we subsequently failed to detect Ruffe eDNA.

Of the 72 samples that tested positive for Ruffe DNA, 40 tested positive in the initial assay with three technical qPCR replicates. The remaining 32 (including the positive cooler blank) detected Ruffe DNA only after a secondary screening of six additional technical qPCR replicates. For sites where Ruffe DNA was detected, detection failure (i.e. "initial false negative"; the percent of samples that tested positive for Ruffe DNA only after a secondary screening of additional DNA extract) ranged from 0 to $57 \%$ (Table 3). On average, approximately $9 \%$ of all the samples taken from locations where Ruffe DNA was ultimately detected failed to detect Ruffe DNA during the initial screening.

\section{Discussion}

The positive eDNA detections reported here are consistent with the pattern of natural spread of Ruffe, including their ongoing advance towards important ballast-water uptake areas like the St. Marys locks in eastern Lake Superior. In accordance with predictions from a ballast-mediated dispersal model (i.e. Sieracki et al. 2014) our results also provide the first indication that Ruffe is present in southern Lake Michigan, which suggests that Ruffe could be much closer to the Mississippi River than has been indicated by surveillance with conventional sampling gears alone. The potential consequences of a widespread invasion of Ruffe in the lower Great Lakes and the Mississippi River basin (see below) suggest that these results warrant consideration of a management response. However, the uncertainty associated with interpretation of positive eDNA detections (sensu Darling 2014) may impede effective 
Table 1 Location, sampling effort, sample date, and number of positive detections for Ruffe DNA

\begin{tabular}{|c|c|c|c|c|}
\hline Site no. & Location & No. of samples & Sample date (s) & $\begin{array}{l}\text { No. of samples with } \\
\text { positive detections }\end{array}$ \\
\hline & Lake Superior basin & & & \\
\hline 1 & Tahquamenon River & $38(11)$ & 21 May 2013 & $29(8)$ \\
\hline 2 & Roxbury Creek & 10 & 21 May 2013 & 1 \\
\hline 3 & Naomikong River & 11 & 21 May 2013 & 1 \\
\hline 4 & Pendills Creek & 14 & 21 May 2013 & 2 \\
\hline 5 & Waiska River & $25(6)$ & 21 May 2013 & $11(3)$ \\
\hline 6 & St. Marys River (West) & $50(6)$ & 20 May 2013 & 0 \\
\hline \multirow[t]{3}{*}{7} & St. Marys River (East) & 26 & 20 May 2013 & 1 \\
\hline & Total & $174(23)$ & & $45(11)$ \\
\hline & Lake Huron basin & & & \\
\hline \multirow[t]{2}{*}{8} & Cheboygan River & 45 & 25 October 2012 & 0 \\
\hline & & $37(7)$ & 22 May 2013 & $8(1)$ \\
\hline \multirow[t]{2}{*}{9} & Trout River & 15 & 25 October 2012 & 0 \\
\hline & & 20 & 22 May 2013 & 1 \\
\hline 10 & Swan River & $18(8)$ & 22 May 2013 & 0 \\
\hline 11 & Norwegian Creek & 6 & 23 May 2013 & 0 \\
\hline \multirow[t]{2}{*}{12} & Thunder Bay River & 53 & 25 October 2012 & 0 \\
\hline & & $49(10)$ & 23 May 2013 & 0 \\
\hline 13 & Squaw Bay & 5 & 23 May 2013 & 0 \\
\hline \multirow[t]{4}{*}{14} & Devils River & 24 & 25 October 2012 & 0 \\
\hline & & 5 & 23 May 2013 & 1 \\
\hline & Total & $277(25)$ & & $10(1)$ \\
\hline & Lake Erie basin & & & \\
\hline 15 & Sandusky River & 50 & 24 June 2013 & 0 \\
\hline \multirow[t]{3}{*}{16} & Maumee River & 48 & 25 June 2013 & 0 \\
\hline & Total & 98 & & 0 \\
\hline & Lake Michigan basin & & & \\
\hline 17 & Calumet Harbor & 32 & 8 July 2013 & 10 \\
\hline 18 & Chicago Waterfront & 50 & 11 September 2013 & 0 \\
\hline \multirow[t]{2}{*}{19} & Milwaukee & 101 & 7 November 2012 & 0 \\
\hline & & $100(11)$ & 16 May 2013 & 0 \\
\hline \multirow[t]{2}{*}{20} & Twin Rivers & 32 & 13 November 2012 & 0 \\
\hline & & $38(5)$ & 29 May 2013 & 1 \\
\hline \multirow[t]{2}{*}{21} & Fox River & 48 & 13 Nov 2012 & 0 \\
\hline & & $50(9)$ & 29 May 2013 & 1 \\
\hline \multirow[t]{2}{*}{22} & Sturgeon Bay & 74 & 15 November 2012 & 0 \\
\hline & & $50(8)$ & 31 May 2013 & $1(1)$ \\
\hline \multirow[t]{2}{*}{23} & Menominee River & 50 & 14 November 2012 & 0 \\
\hline & & $44(6)$ & 30 May 2013 & 0 \\
\hline \multirow[t]{4}{*}{24} & Escanaba River & $36(10)$ & 14 November 2012 & 0 \\
\hline & & $35(6)$ & 30 May 2013 & $4(1)^{\mathrm{a}}$ \\
\hline & Total & $740(55)$ & & $17(2)$ \\
\hline & Grand total & $1289(103)$ & & $72(14)$ \\
\hline
\end{tabular}

Number of benthic samples is indicated in parentheses

${ }^{a}$ One of these four positives was a cooler blank. All remaining cooler blanks $(n=47)$ and equipment controls $(n=1$ for each positive) tested negative for Ruffe DNA 
Table 2 Comparison of eDNA versus conventional fisheries surveillance (from both dedicated and incidental capture efforts) for all sites where eDNA surveillance was conducted in 2012 and 2013

\begin{tabular}{|c|c|c|c|c|c|}
\hline \multirow[t]{2}{*}{ Site no. } & \multirow[t]{2}{*}{ Location } & \multicolumn{2}{|l|}{ eDNA } & \multicolumn{2}{|l|}{ Conventional } \\
\hline & & Effort & \# Pos. & Effort $^{\mathrm{e}}$ & \# Ruffe \\
\hline & Lake Superior basin & & & & \\
\hline 1 & Tahquamenon River & 38 & 29 & PAT (207) & 0 \\
\hline 2 & Roxbury Creek & 10 & 1 & $\mathrm{n} / \mathrm{a}$ & $\mathrm{n} / \mathrm{a}$ \\
\hline \multirow[t]{3}{*}{3} & Naomikong River & 11 & 1 & SEN (12) & 0 \\
\hline & & & & GN 1 (12) & 0 \\
\hline & & & & GN 2 (12) & 0 \\
\hline \multirow[t]{3}{*}{4} & Pendills Creek & 14 & 2 & SEN (12) & 0 \\
\hline & & & & GN 1 (12) & 0 \\
\hline & & & & GN 2 (12) & 0 \\
\hline 5 & Waiska River & 25 & 11 & $\mathrm{n} / \mathrm{a}$ & $\mathrm{n} / \mathrm{a}$ \\
\hline \multirow[t]{3}{*}{6} & St. Marys River (West) & 50 & 0 & FN 1 (34) & 0 \\
\hline & & & & BT-4.9 (2.1) & 0 \\
\hline & & & & EF $1(5.8)$ & 0 \\
\hline \multirow[t]{2}{*}{7} & St. Marys River (East) & 26 & 1 & BT-4.9 (4) & 0 \\
\hline & Lake Huron basin & & & & \\
\hline \multirow[t]{3}{*}{8} & Cheboygan River & 82 & 8 & BT-4.9 (0.5) & 0 \\
\hline & & & & $\mathrm{EF}(2.4)$ & 0 \\
\hline & & & & PT (214) & 1 \\
\hline \multirow[t]{2}{*}{9} & Trout River & 35 & 1 & EF $3(1.0)$ & 0 \\
\hline & & & & SPT (102) & 0 \\
\hline 10 & Swan River & 18 & 0 & $\mathrm{n} / \mathrm{a}$ & $\mathrm{n} / \mathrm{a}$ \\
\hline 11 & Norwegian Creek & 6 & 0 & $\mathrm{n} / \mathrm{a}$ & $\mathrm{n} / \mathrm{a}$ \\
\hline \multirow[t]{9}{*}{12} & Thunder Bay River ${ }^{a}$ & 102 & 0 & BT-4.9 (1.8) & 0 \\
\hline & & & & EF 1 (6.9) & 0 \\
\hline & & & & TN (109) & 0 \\
\hline & & & & BT-5.3 (4.3) & 0 \\
\hline & & & & BT-11 (10) & 0 \\
\hline & & & & GN 4 (16) & 0 \\
\hline & & & & GN 5 (18) & 0 \\
\hline & & & & GN 6 (1399) & 0 \\
\hline & & & & GN 7 (1750) & 0 \\
\hline 13 & Squaw Bay & 5 & 0 & $\mathrm{n} / \mathrm{a}$ & $\mathrm{n} / \mathrm{a}$ \\
\hline \multirow[t]{2}{*}{14} & Devil's River & 29 & 1 & FN 4 (122) & 0 \\
\hline & Lake Erie basin & & & & \\
\hline \multirow[t]{3}{*}{15} & Sandusky River ${ }^{\mathrm{b}}$ & 50 & 0 & BT-4.9 (2.9) & 0 \\
\hline & & & & EF 1 (2.5) & 0 \\
\hline & & & & FN 5 (3) & 0 \\
\hline \multirow[t]{3}{*}{16} & Maumee River ${ }^{\mathrm{c}}$ & 48 & 0 & BT-4.9 (3.1) & 0 \\
\hline & & & & FN 5 (15) & 0 \\
\hline & Lake Michigan basin & & & & \\
\hline 17 & Calumet Harbor & 32 & 10 & $\mathrm{n} / \mathrm{a}$ & $\mathrm{n} / \mathrm{a}$ \\
\hline
\end{tabular}


Table 2 continued

\begin{tabular}{|c|c|c|c|c|c|}
\hline \multirow[t]{2}{*}{ Site no. } & \multirow[t]{2}{*}{ Location } & \multicolumn{2}{|l|}{ eDNA } & \multicolumn{2}{|l|}{ Conventional } \\
\hline & & Effort & \# Pos. & Effort $^{\mathrm{e}}$ & \# Ruffe \\
\hline 18 & Chicago Waterfront & 50 & 0 & $\mathrm{n} / \mathrm{a}$ & $\mathrm{n} / \mathrm{a}$ \\
\hline \multirow[t]{4}{*}{19} & \multirow[t]{4}{*}{ Milwaukee } & \multirow[t]{4}{*}{201} & \multirow[t]{4}{*}{0} & EF 2 (8) & 0 \\
\hline & & & & FN 2 (6) & 0 \\
\hline & & & & FN 3 (6) & 0 \\
\hline & & & & MT (10) & 0 \\
\hline 20 & Twin Rivers & 70 & 1 & PAT (79) & 0 \\
\hline 21 & Fox River & 98 & 1 & $\mathrm{n} / \mathrm{a}$ & $\mathrm{n} / \mathrm{a}$ \\
\hline 22 & Sturgeon Bay & 124 & 1 & $\mathrm{n} / \mathrm{a}$ & $\mathrm{n} / \mathrm{a}$ \\
\hline \multirow[t]{4}{*}{23} & \multirow[t]{4}{*}{ Menominee River } & \multirow[t]{4}{*}{94} & \multirow[t]{4}{*}{0} & PAT (74) & 0 \\
\hline & & & & EF 2 (8) & 0 \\
\hline & & & & BT-3.7 (1.7) & 0 \\
\hline & & & & GN 3 (12) & 0 \\
\hline \multirow[t]{4}{*}{24} & \multirow[t]{4}{*}{ Escanaba River $^{\mathrm{d}}$} & \multirow[t]{4}{*}{71} & \multirow[t]{4}{*}{4} & BT-3.7 (5) & 3 \\
\hline & & & & GN EX (4682) & 4 \\
\hline & & & & BT-4.9 (1.1) & 0 \\
\hline & & & & GN 3 (32) & 9 \\
\hline
\end{tabular}

Effort is reported as the composite of all 2012 and 2013 sampling. Data for conventional surveillance is taken from Bowen and Goehle (2012) and Bowen and Keppner (2013). For eDNA, effort is reported as the number of 2L water samples taken and '\# pos.' is the number of positive eDNA detections. For conventional methods the type of sampling gear used is reported and the '\# Ruffe' is the number of Ruffe captured

a Includes Thunder Bay

b Includes Sandusky Bay

c Includes Maumee Bay

d Includes Little Bay de Noc

e Gears used for conventional sampling included (with appropriate units of effort in parentheses): FN $1=$ paired fyke nets, 4.7 mm mesh with $15 \mathrm{~m}$ lead (trapnights); BT-4.9 = bottom trawl with $4.9 \mathrm{~m}$ head rope (h); EF $1=$ electrofishing (h); SEN = seine, $46 \mathrm{~m}$ length (no. of hauls); GN 1 = gillnet, $21 \mathrm{~m}$ with 9.5-38 mm mesh (no. of sets); GN 2 = gillnet, $37 \mathrm{~m}$, with $25 \mathrm{~mm}$ mesh (no. of sets); PAT = portable assessment trap (trapnights); EF $2=$ electrofishing (events); FN $2=$ fyke net, $0.9 \mathrm{~m} \times 1.5 \mathrm{~m}$ box with $12.7 \mathrm{~mm} \# 126 \mathrm{mesh}$ (trapnights); FN 3 = mini fyke net, $0.7 \mathrm{~m} \times 1.0 \mathrm{~m}$ box with 3.175 \#35 mesh (trapnights); MT = minnow trap array, 5 baited traps spaced $7.6 \mathrm{~m}$ apart on one line (arrays); BT-3.7 = bottom trawl with $3.7 \mathrm{~m}$ head rope (h); GN $3=$ gillnet, $97.5 \mathrm{~m}$ including panel of $25 \mathrm{~mm}$ stretch mesh (no. of sets); GN EX = gillnet, experimental with $25-127 \mathrm{~mm}$ mesh (meters); $\mathrm{TN}=$ trapnet, small mesh (trapnights); BT-5.3 = bottom trawl with $5.3 \mathrm{~m}$ head rope (h); BT-11 = bottom trawl with $11 \mathrm{~m}$ head rope (h); GN 4 = gillnet, graded mesh including panel of $38.1 \mathrm{~mm}$ stretch mesh (no. of sets); GN 5 = gillnet, micromesh including panels of 12.7, 15.9, and $19.1 \mathrm{~mm}$ stretch mesh (no. of sets); GN $6=$ gillnet, graded mesh including panel of $38.1 \mathrm{~mm}$ stretch mesh (meters); GN 7 = gillnet, micromesh including panels of 12.7, 15.9, and $19.1 \mathrm{~mm}$ stretch mesh (meters); PT = permanent trap (trapnights); EF 3 = backpack electrofishing (h); SPT = semi-permanent trap (trapnights); FN $4=$ fyke net (trapnights); FN $5=$ paired fyke net (trapnights)

decision-making and, given the reasonable fear of wasting resources if results do not indicate the presence of fish, resource managers may be reluctant to initiate expensive response efforts based only on positive eDNA detections (Finnoff et al. 2007; Darling and Mahon 2011). To allay management concerns, sources of error and uncertainty and the strength of evidence for the presence of live fish need to be communicated (Darling 2014). We attempt to put the results reported above into that context. We present our eDNA surveillance results within a conceptual two-dimensional management response framework based on weight of evidence for species presence and species spread potential (Fig. 2).

Our conceptual model is based, in part, on the idea from Jerde et al. (2011) that a gradient of evidence for species presence exists that is related to number and frequency of eDNA observations. We make the 
Table 3 Total number of samples, number testing positive for Ruffe DNA, and percent positive samples for both the initial screening (i.e. with three technical qPCR replicates) and the re- screening (i.e. with six technical qPCR replicates) for eDNA samples collected in 2013

\begin{tabular}{|c|c|c|c|c|c|c|c|}
\hline \multirow[t]{2}{*}{ Site no. } & \multirow[t]{2}{*}{ Location } & \multicolumn{3}{|c|}{ Initial screening } & \multicolumn{2}{|l|}{ Re-screen } & \multirow{2}{*}{$\begin{array}{l}\text { Detection } \\
\text { failure (\%) }\end{array}$} \\
\hline & & No. samples & $\begin{array}{l}\text { No. samples } \\
\text { positive }\end{array}$ & $\%$ positive & No. samples & No. samples positive & \\
\hline 1 & Tahquamenon River & 38 & 17 & 44.7 & 21 & 12 & 57.1 \\
\hline 5 & Waiska River & 25 & 10 & 40.0 & 15 & 1 & 6.7 \\
\hline 17 & Calumet Harbor & 32 & 8 & 25.0 & 24 & 2 & 8.3 \\
\hline 8 & Cheboygan River & 37 & 3 & 8.1 & 34 & 5 & 14.7 \\
\hline 9 & Trout River & 20 & 1 & 5.0 & 19 & 0 & 0.0 \\
\hline 7 & St. Marys River & 26 & 1 & 3.8 & 25 & 0 & 0.0 \\
\hline 4 & Pendills Creek & 14 & 0 & 0.0 & 14 & 2 & 14.3 \\
\hline 3 & Naomikong River & 11 & 0 & 0.0 & 11 & 1 & 9.1 \\
\hline 2 & Roxbury Creek & 10 & 0 & 0.0 & 10 & 1 & 10.0 \\
\hline 14 & Devils River & 5 & 0 & 0.0 & 5 & 1 & 20.0 \\
\hline 21 & Fox River & 50 & 0 & 0.0 & 50 & 1 & 2.0 \\
\hline 20 & Twin Rivers & 38 & 0 & 0.0 & 38 & 1 & 2.6 \\
\hline 22 & Sturgeon Bay & 50 & 0 & 0.0 & 50 & 1 & 2.0 \\
\hline \multirow[t]{2}{*}{24} & Escanaba River ${ }^{\mathrm{a}}$ & 34 & 0 & 0.0 & 34 & 3 & 8.8 \\
\hline & Total & 390 & 40 & 10.3 & 350 & 31 & 8.9 \\
\hline
\end{tabular}

The number of samples that were re-screened from each location is the subset of samples that failed to detect Ruffe DNA during the initial screen. Thus, detection failure is equivalent to the percent of samples in which target DNA was detected during re-screening. For all locations included in the table, at least one sample tested positive for Ruffe DNA

${ }^{\text {a }}$ Excludes cooler control

assumption that evidence to support species presence is stronger when a pathway of invasion (including natural dispersal) exists and, thus, we incorporate invasion potential as part of the weight of evidence axis. The second axis considers potential for spread from the detection site (e.g. presence of vectors for secondary spread, proximity to vectors, and potential for natural dispersal). Though not explicitly considered in our conceptual model, the potential for negative impacts of species establishment at a site could also be considered as an additional axis, including measures of site vulnerability (i.e. ecological or economic values that could be impacted if the site is invaded, sensu Margules and Pressey 2000).

In three of the six locations where we detected eDNA from more than one sample, our results simply confirm previous records of live fish from the site (sites 1, 8, 24). At Pendills Creek and Waiska River, multiple positive detections are consistent with continued eastward expansion of Ruffe along the southern shoreline of Lake Superior and also probably indicate the presence of live fish (sites 4 and 5; Fig. 3). Pendills Creek and Waiska River are both within $50 \mathrm{~km}$ of the Tahquamenon River and, thus, well within range for natural dispersal of Ruffe based on a conservative estimate of Ruffe dispersal distance ( $\sim 25 \mathrm{~km} /$ year; Sieracki et al. 2014).

Multiple positive detections of Ruffe DNA in southern Lake Michigan at Calumet Harbor suggest a major range expansion, but this result is consistent with predictions from a ballast-mediated dispersal model that indicates high probability of Ruffe introduction in southern Lake Michigan ports (Fig. 3, site 17; Sieracki et al. 2014). We cannot rule out the possibility that the eDNA we detected in Calumet Harbor was introduced into the system via discharged ballast water sourced from a Ruffe-invaded port, but that possibility seems unlikely for two reasons. First, eDNA degradation 


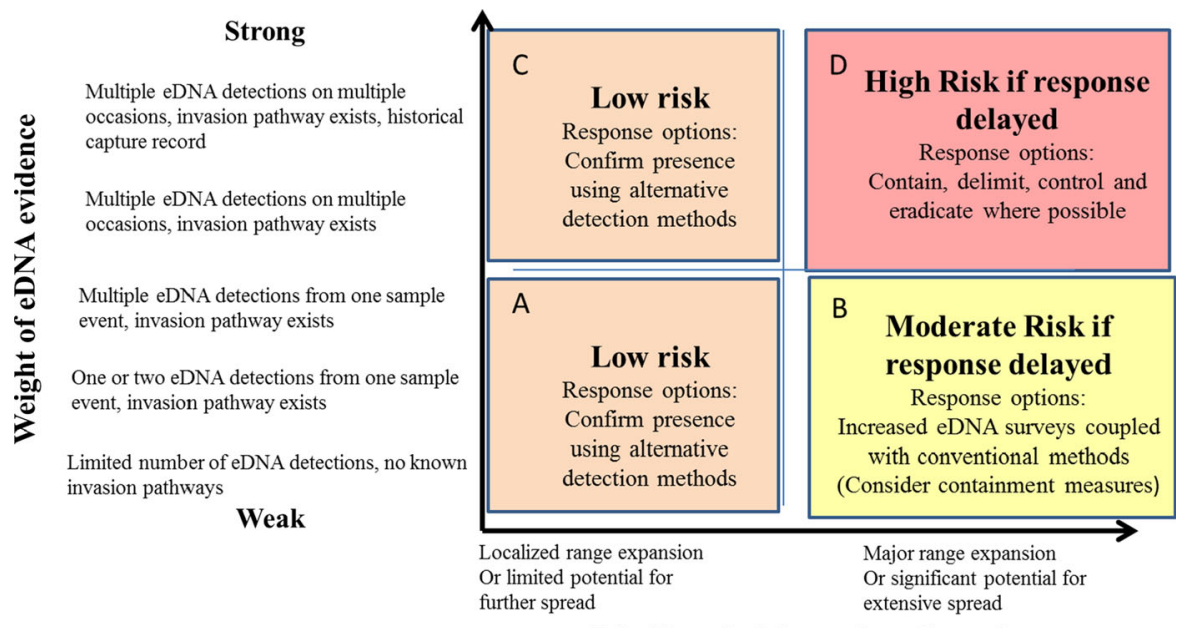

Likelihood of Secondary Spread

Fig. 2 A conceptual management framework for responding to eDNA surveillance results. Response actions can be influenced by both the weight of evidence in favor of species presence and the likelihood of secondary spread. The strongest eDNA evidence in favor of species presence is evidence that, agrees with predictions from natural spread and/or dispersal models (i.e. presence of an invasion pathway), indicates a pattern of repeated detection over time, and/or corroborates any record(s) of historical live capture. The potential for spread could include consideration of presence of vectors for secondary spread, proximity to vectors, and potential for natural dispersal
Fig. 3 The conceptual management framework as applied to the eDNA survey results from 2012/2013 Ruffe eDNA surveillance effort (circled numbers correspond to site numbers listed in Table 1). Ruffe dispersal to all sampling locations was conceivable based on natural spread or dispersal model predictions

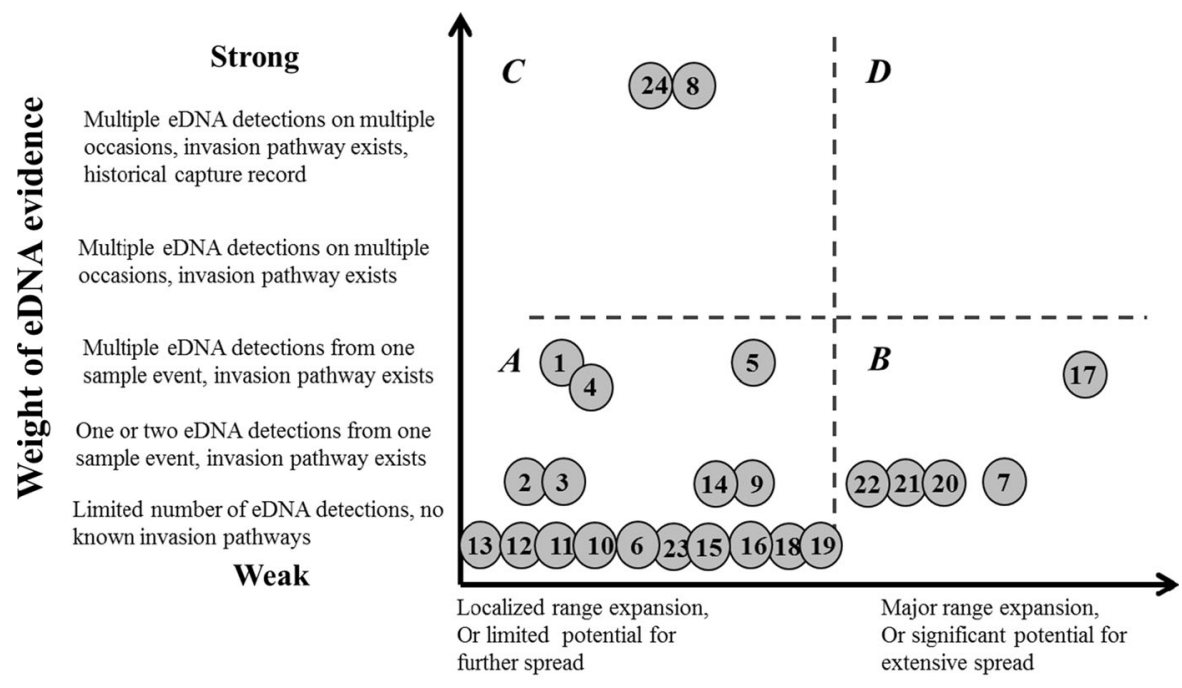

Likelihood of Secondary Spread studies using ambient water suggest that the majority of suspended Ruffe DNA would degrade in the time required to transit from the nearest Ruffe invaded port ( 24 h; Barnes et al. 2014). Second, although seven commercial vessels entered the port at Calumet in the 1-month period prior to our survey in Calumet Harbor (on July 8, 2013), none of these vessels was traveling directly from a port where Ruffe have been reported (National Ballast Information Clearinghouse 2014). Thus, it seems likely that the DNA detected in Calumet indicates the presence of live Ruffe in the harbor. Any future eDNA sampling that produces repeated 
detections over time, especially during intervals with no ballast-water discharge, would strengthen this conclusion (Fig. 2). A large number of eDNA samples collected from Calumet Harbor over a 2- to 4-week window could be especially informative, as such sampling would provide the spatial and temporal replicates required to resolve whether positive detections are a result of a pulse, non-fish vector or indicative of a sustained source of live fish.

At a number of sites, Ruffe DNA was recorded from a single sample, thus, representing the weakest evidence for the presence of live fish (Fig. 2). We cannot rule out that some of these detections may have arisen from low levels of contamination, as can be expected occasionally even when observing strict quality assurance protocols (Apfalter et al. 2005; Turner 2015) and as evidenced by the detection of Ruffe DNA in one of our cooler blanks. However, we found no evidence of systemic contamination in our laboratory or field control samples and all sites where a single positive sample was detected are locations where Ruffe have been captured previously (i.e. site 9) or are within approximately $100 \mathrm{~km}$ of sites where live fish have previously been collected and, thus, within range for natural dispersal of Ruffe (e.g. sites 20-22 are plausible given their proximity to the Escanaba and Menominee rivers where Ruffe were first captured in 2002 and 2007, respectively). Together, these observations suggest contamination had little effect on the patterns of detection reported here. It is also a possibility that some of these positive detections are a result of discharged ballast water sourced from a Ruffe-invaded port, although in most cases this seems unlikely given that most of the positive detections we report occurred at sites without an active port or in habitats upstream of existing port facilities. One exception is the positive detection at Fox River (WI), where the sample was taken near the mouth of the river and adjacent to the shipping channel.

Darling and Mahon (2011) make the case that managers should be wary of the risks associated with a failure to detect DNA of target AIS when it is present (i.e. false negative), given that highly sensitive eDNA surveillance methods make detection of incipient invasions a real possibility and, thus, increase the potential to minimize long-term control costs and impacts if establishment can be prevented. In this study, we screened samples using a quantitative PCR assay to reduce the rate of false negatives (i.e. relative to less sensitive traditional PCR methods; sensu Thomsen et al. 2012a, b; Wilcox et al. 2013; Nathan et al. 2014; Turner et al. 2014a, b). Yet, after doubling our level of replication we detected numerous additional positive samples (Table 3). In the Tahquamenon River, where Ruffe have been collected since 2006, 12 out of the 29 samples that eventually tested positive for Ruffe were negative during the initial qPCR screening (3 replicates), suggesting that the concentration of target species DNA is low and highly patchy both within an extracted sample and in the environment (i.e. $25 \%$ of samples collected tested negative despite Ruffe presumably being established at low densities at this site). Patchiness of eDNA is consistent with the occurrence of a substantial portion of eDNA in relatively large particles (i.e. particle sizes corresponding to cells or clumps of cells; Turner et al. 2014a, b). Furthermore, many locations had a relatively low number of positive sample detections ( $<5 \%$ of samples positive at a location). This is expected if there are few Ruffe releasing eDNA and imperfect mixing of the water column (Jerde and Mahon 2015). If we assume that Ruffe are physically present in these locations with very few positive detections, then presumably there is a large false negative rate (see "Appendix 2: A method for estimating the sensitivity of the Ruffe eDNA survey" section). This is a critical consideration in locations where no positive detections were recorded and where there was a limited sampling effort (locations with fewer than 30 samples collected). The results from our re-screening are consistent with other eDNA studies that highlight the importance of PCR replication and the potential for high prevalence of false negatives from eDNA samples when detection probabilities are low (Ficetola et al. 2015; Furlan et al. 2015).

It follows that decision makers may be more willing to initiate potentially expensive and long-term response programs, where the cost of the failure to act is high (Darling and Mahon 2011). Although effects of Ruffe populations in Lake Superior are equivocal, it is possible that impacts on food webs in other parts of the Great Lakes or connected basins could be larger, especially if populations become large or widespread (Bronte et al. 1998; Gunderson et al. 1998). Ruffe can compete with native Great Lakes fishes for space and food (Edsall et al. 1993; Sierszen et al. 1996; Ogle et al. 2004; Fullerton and Lamberti 2005). It has also been suggested that complete 
colonization of the Great Lakes by Ruffe could result in a decrease in Yellow Perch populations by 10-60\% and of Whitefish and Walleye populations by up to $25 \%$ with accompanying annual losses in the range of $\$ 24$ to \$214 million in sportfishing and commercial fishing revenue (Leigh 1998). In addition, the establishment of Ruffe in the southern basin of Lake Michigan would likely accelerate spread out of the Great Lakes and into the Mississippi River basin via the Chicago Area Waterway System. Ruffe was identified as one of 29 species (and one of six fishes) with the potential to cause moderate to severe effects if introduced into the Mississippi River basin (Jerde et al. 2010; US Army Corps of Engineers 2014). The extent of the threat to the Mississippi basin is as yet unquantified, but globally significant freshwater biodiversity is potentially at risk because the Mississippi River and its tributaries contain the largest number of freshwater fishes (260 species) of any region at comparable latitudes (Smith 1981; Fremling et al. 1989) and are a global center of diversity and endemism for crayfish (Lodge et al. 2012) and unionid mussels (Abell et al. 2000). Some native fishes serve as important hosts for endangered unionid mussels and a subset of these host fishes rely heavily on benthic food sources (e.g. Freshwater Drum, Sauger, and Catfishes), and are expected to compete directly with Ruffe (Ed Rutherford, NOAA GLERL, personal communication, December 10, 2013).

Given the detection of Ruffe eDNA in Calumet and the potential risk to the Mississippi River basin there may be value in implementing ongoing surveillance for Ruffe with both eDNA and conventional sampling methods, and managers might consider adopting measures to contain and prevent the movement of Ruffe out of the Great Lakes via the Chicago Area Water System (Fig. 3). In addition, the detection of Ruffe eDNA near important ballast-water uptake areas (sites 7 and 21; Jennifer Sieracki, National Park Service, personal communication, June 24, 2015) highlights further the invasion risk posed by the movement of ballast water within the Great Lakes (Keller et al. 2011; Adebayo et al. 2014; Sieracki et al. 2014). Thus, other slow-the-spread and control options proposed early in the Ruffe invasion, including ballast- water management, might also be productively revisited by managers (Busiahn 1997).

While the capture of a live specimen will always be more compelling than eDNA evidence, we caution against dismissal of eDNA results in the absence of corroborating live captures, especially in the absence of an explicit examination of relative sampling effort and detection sensitivity of conventional gears. There is increasing evidence that genetic surveillance methods are more sensitive than conventional approaches (Jerde et al. 2011; Thomsen et al. 2012a, b; Turner et al. 2012; Biggs et al. 2015; Valentini et al. 2015), which means that eDNA detections are possible even when sampling with conventional gear fails-especially at the putative invasion front when target organisms are rare (Darling and Mahon 2011; Jerde et al. 2011; Dejean et al. 2012). Controlled experiments that directly compare the sensitivity of eDNA sampling and conventional sampling methods when target species are at low abundance would be helpful (Darling and Mahon 2011). Fuller consideration of dispersal, invasion pathways, and other factors affecting invasion risk would provide a stronger basis for management response decisions following the eDNA detection of a potential incipient invasion. Only when eDNA detections are considered alongside other lines of evidence (including probability of spread and potential for negative impacts) can they help guide appropriate and defensible management decisions.

Acknowledgments Funding for this work was provided by the US Environmental Protection Agency's Great Lakes Restoration Initiative through Cooperative Agreement No. 30181 AJ326 between the US Fish and Wildlife Service (USFWS) and the University of Notre Dame and Grant No. NA09NOS4780192 awarded by the National Oceanic and Atmospheric Administration's Center for Sponsored Coastal Ocean Research (NOAA CSCOR) to the University of Notre Dame, and through Grant No. NA10NOS4780218 awarded by NOAA CSCOR. We thank the USFWS Ashland FWCO for providing Ruffe specimens and J. Baker with the Ohio State Museum of Biological Diversity for providing tissue samples for Percidae species for marker development. M. Hoff, B. Eggold, D. Boyarski, C. Olds, Lake Superior State University Aquatic Research Laboratory, and the Bay Mills Indian Community provided logistical support. We thank the many individuals who provided field and/or lab support. C. Turner, E. Grey, M. Barnes, and B. Olds provided helpful comments in discussing the eDNA results. This is GLERL contribution number 1798.

Open Access This article is distributed under the terms of the Creative Commons Attribution 4.0 International License (http:// creativecommons.org/licenses/by/4.0/), which permits unrestricted use, distribution, and reproduction in any medium, provided you give appropriate credit to the original author(s) and the source, provide a link to the Creative Commons license, and indicate if changes were made. 


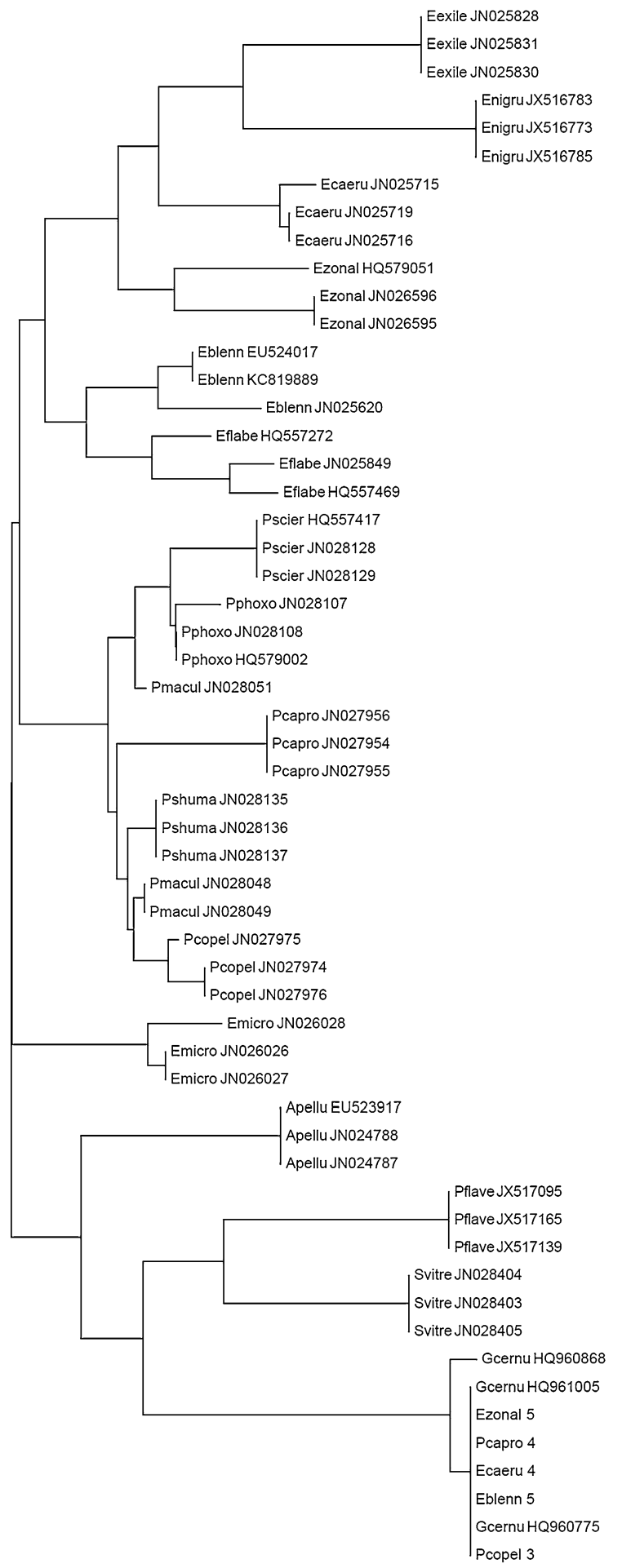

4Fig. 4 Neighbor-Joining phylogenetic tree for G. cernua and 17 co-occuring Percidae species in the Great Lakes basin. A Sequencher ${ }^{\text {TM }}$ (GeneCodes) file was built with COI sequences downloaded from GenBank (accession numbers listed for each sequence in the tree) in addition to the sequences resulting from qPCR amplifications (Eblenn 5, Ecaeru 4, Ezonal 5, Pcapro 4, and Pcopel 3). All sequences were trimmed by eye, leaving a 63-bp consensus sequence. The Neighbor-Joining phylogenetic tree was built in MEGA 5.1 (Tamura et al. 2011) using the number of base-pair differences as the determining factor for the branch lengths. The tree indicates contamination at some level of the tissue collection, storage, or DNA extraction processes (negative controls were included with the qPCR assays and all failed to amplify), but it is evident that the markers are ideal for amplifying only DNA from the target species, $G$. cеrnua

\section{Appendix 1: Detailed description of methods for qPCR marker development}

Species-specific markers for G. cernua were generated from each file of sequences with PrimerHunter (Duitama et al. 2009). Potential primer pairs were further evaluated by Primer Express ${ }^{\circledR} 3.0$ (Life Technologies) to identify primer sets adhering to the stringent parameters of the qPCR assay. A total of 5 potential primer pairs, 3 from the COI and 2 from the control region, were ordered from Integrated DNA Technologies (http://www.idtdna.com). All 5 primer pairs were evaluated with tissue-extracted DNA from both G. cernua and 17 additional Percidae species historically found in the Great Lakes basin: Ammocrypta pellucida, E. caeruleum, E. blennoides, E. exile, E. flabellare, E. microperca, E. nigrum, E. spectabile, E. zonale, Perca flavescens, P. caprodes, P. copelandi, P. maculata, P. phoxocephala, P. sciera, P. shumardi, and Sander vitreus (Fig. 4; Table 4).

\section{Appendix 2: A method for estimating the sensitivity of the Ruffe eDNA survey}

The purpose of this exercise is to estimate a false negative rate for the Ruffe samples collected in 2012/2013 and screened using nine qPCR technical replicates. We do not have a solid understanding of the density of Ruffe in any of the locations, so we will 
Table 4 Percent similarity of COI primers to Ruffe and co-occurring Percidae species in the Great Lakes basin

\begin{tabular}{|c|c|c|c|c|}
\hline Scientific name & Number of sequences & Forward primer $(\%)$ & Reverse primer $(\%)$ & Together $(\%)$ \\
\hline Gymnocephalus cеrnиа & 31 & $87-100$ & $96-100$ & $92-100$ \\
\hline Ammocrypta clara & 10 & 79 & 80 & 79 \\
\hline Ammocrypta pellucida & 9 & 83 & 80 & 81 \\
\hline Etheostoma caeruleum & 71 & $70-74$ & $64-72$ & $67-73$ \\
\hline Etheostoma chlorosomum & 8 & $70-83$ & $76-80$ & $73-81$ \\
\hline Etheostoma exile & 14 & 78 & 76 & 77 \\
\hline Etheostoma flabellare & 32 & $65-78$ & $64-84$ & $65-81$ \\
\hline Etheostoma microperca & 23 & 78 & $72-76$ & $75-77$ \\
\hline Etheostoma nigrum & 225 & $70-83$ & 72 & $71-77$ \\
\hline Etheostoma olmstedi & 159 & $70-83$ & $72-80$ & $71-81$ \\
\hline Etheostoma spectabile & 80 & $70-83$ & $68-80$ & $69-81$ \\
\hline Etheostoma zonale & 25 & $74-83$ & $76-80$ & $75-81$ \\
\hline Perca flavescens & 24 & $70-74$ & 72 & $71-73$ \\
\hline Percina caprodes & 53 & $74-78$ & 72 & $73-75$ \\
\hline Percina copelandi & 13 & 74 & 72 & 73 \\
\hline Percina evides & 19 & 70 & 72 & 71 \\
\hline Percina maculata & 17 & 83 & 72 & 77 \\
\hline Percina microlepida & 13 & 78 & 72 & 75 \\
\hline Percina phoxocephala & 11 & $74-78$ & 72 & $73-75$ \\
\hline Percina scieri & 13 & 78 & $64-76$ & $71-77$ \\
\hline Percina shumardi & 9 & $74-78$ & 72 & $73-75$ \\
\hline Sander canadensis & 6 & 78 & 84 & 81 \\
\hline Sander vitreus & 11 & 70 & 84 & 77 \\
\hline
\end{tabular}

Percent similarity is estimated as [(number of matching bases/total number of bases in primer) $\times 100$ ]. Table includes the Number of sequences downloaded from GenBank per species, percent similarity for the Forward primer, percent similarity for the Reverse primer, and percent similarity when considering both primers Together

necessarily treat each location independently from each other.

First, there are some locations that had no detections of Ruffe. We cannot estimate a false negative rate as we have no indication that Ruffe are present. These locations are: Milwaukee, St Marys River (west), Swan River, Thunder Bay River, Norwegian Creek, Squaw Bay, Menominee, Sandusky River, Maumee River, and Chicago waterfront. This leaves us with 14 locations with at least one positive detection in a sample (Table 5).

Let us start by considering the technical replicates from Tahquamenon. The data of the number of positive technical replicates per sample look as such: $\{2,1,8,3,1,1,6,1,8,2,3,1,1,0,0,2,3$, $8,0,0,0,0,1,0,9,0,9,9,1,9,9,1,7,1,9,9$, 9 \}. Note that $21 \%$ of samples (8/37) are zero. We can estimate $p$, the probability any given technical replicate is positive using the Log Likelihood of a binomial function with a maximum of 9 technical replicates per samples as, $L L(p)=$ $\sum_{i=1}^{37} \log \left(\left(\begin{array}{c}9 \\ x_{i}\end{array}\right)\left(p^{x_{i}}\right)(1-p)^{9-x_{i}}\right)$ and then finding the value of $p$ that maximizes this function, which results in an MLE, $\hat{p}=0.4$. With this estimate, the 
Table 5 Locations with positive Eurasian Ruffe detections

\begin{tabular}{|c|c|c|c|}
\hline Location & $\mathrm{n}$ & $\begin{array}{l}\text { Number of samples with } \\
\text { at least one positive } \\
\text { replicate }\end{array}$ & Data: number of positive technical replicates per sample (9 max) \\
\hline Sugar Island & 25 & 1 & $1,0,0,0,0,0,0,0,0,0,0,0,0,0,0,0,0,0,0,0,0,0,0,0,0$ \\
\hline Waiska & 24 & 11 & $0,0,0,0,0,0,0,0,0,0,7,8,9,0,9,1,9,9,9,0,0,9,9,9$ \\
\hline Pendills & 13 & 2 & $0,0,0,0,0,1,0,0,0,0,1,0,0$ \\
\hline Naomikong & 11 & 1 & $0,0,0,0,0,0,0,0,1,0,0$ \\
\hline Roxbury & 9 & 1 & $0,0,0,0,1,0,0,0,0$ \\
\hline Tahquamenon & 37 & 29 & $\begin{array}{l}2,1,8,3,1,1,6,1,8,2,3,1,1,0,0,2,3,8,0,0,0,0,1,0,9,0,9,9,1 \\
\quad 9,9,1,7,1,9,9,9\end{array}$ \\
\hline Cheboygan & 35 & 8 & $\begin{array}{l}1,0,0,0,0,0,0,0,0,0,0,0,0,0,0,0,0,0,0,1,0,2,6,1,0,0,1,1,0,0 \text {, } \\
\quad 0,4,0,0,0\end{array}$ \\
\hline Trout & 19 & 1 & $0,0,0,0,0,0,0,0,0,2,0,0,0,0,0,0,0,0,0$ \\
\hline Devils River & 5 & 1 & $0,0,0,0,1$ \\
\hline Fox River & 48 & 1 & $\begin{array}{l}0,0,0,0,0,0,0,0,0,0,0,0,0,0,0,0,0,0,0,0,0,0,0,1,0,0,0,0,0 \\
\quad 0,0,0,0,0,0,0,0,0,0,0,0,0,0,0,0,0,0,0\end{array}$ \\
\hline Twin River & 35 & 1 & $\begin{array}{l}0,0,0,0,0,0,0,0,0,1,0,0,0,0,0,0,0,0,0,0,0,0,0,0,0,0,0,0,0,0 \\
\quad 0,0,0,0,0\end{array}$ \\
\hline Escanaba & 33 & 3 & $\begin{array}{l}1,0,1,1,0,0,0,0,0,0,0,0,0,0,0,0,0,0,0,0,0,0,0,0,0,0,0,0,0,0 \text {, } \\
\quad 0,0,0\end{array}$ \\
\hline Sturgeon Bay & 44 & 1 & $\begin{array}{l}0,0,0,0,0,0,0,0,0,0,0,0,0,0,0,0,0,1,0,0,0,0,0,0,0,0,0,0,0,0 \\
\quad 0,0,0,0,0,0,0,0,0,0,0,0,0,0\end{array}$ \\
\hline Calumet & 29 & 9 & $3,2,0,0,0,3,7,1,0,0,0,0,0,0,0,0,0,0,0,0,0,0,0,0,1,0,1,2,1$ \\
\hline
\end{tabular}

probability of getting nine zeros by chance is $p(0)=0.009$. If we collected 37 samples then the expected number of samples that are false negatives is the number of collected samples $* p(0)=37$ $* 0.009=0.33$. We would conclude it is unlikely that any of the zeros observed at this location are due to false negatives. As the probability of positive detection decreases, we expect the chance of getting nine technical replicates without a positive to increase. If we apply the same logic to all locations with positive Eurasian Ruffe detections we get the following results (Table 6).

The majority of locations have so few positive detections ( 1 replicate in 1 sample) that if we assume the one positive detection is due to presence of Eurasian Ruffe, then there was insufficient technical replication to ensure absence of target DNA (or concentrations below detectable levels). However, for Waiska and Tahquamenon, we can safely conclude that most of the samples that had no target DNA detected were absent of the target DNA - that is to say, a very low false negative rate. The inference from Calumet is not as clear as Waiska and Tahquamenon. It suggests that upwards of $65 \%$ of the samples (13.6/ 20) with no detection may be false negatives, leaving room for some true negatives to be present in the system.

Sensitivity, or the probability of detecting target DNA given it is present at a site, will ultimately depend on the survey method and characteristics of the survey sites, especially the concentration and dispersion of target DNA molecules at a site. Because we do not know the concentration or dispersion of DNA in the sites where we sampled our approach is 
Table 6 Sensitivity of the Ruffe eDNA survey for sites with at least one positive eDNA detection based on a Maximum-likelihood estimation of the probability that any given $\mathrm{qPCR}$ technical replicate is positive

\begin{tabular}{|c|c|c|c|c|c|c|}
\hline Location & $\mathrm{n}$ & $\begin{array}{l}\text { No. of samples } \\
\text { with no detection }\end{array}$ & $\begin{array}{l}\text { Prob. } \\
\text { positive } \\
\text { replicate } \\
\text { ( } p \text {-hat) }\end{array}$ & $\begin{array}{l}\text { Prob. of nine technical } \\
\text { replicate by chance } \\
(p(0))\end{array}$ & $\begin{array}{l}\text { Expected number of } \\
\text { false negatives by } \\
\text { chance }\end{array}$ & Conclusion \\
\hline Sugar Island & 25 & 24 & 0.0044 & 0.96 & 24 & $\begin{array}{l}\text { Insufficient technical } \\
\text { replication }\end{array}$ \\
\hline Waiska & 24 & 13 & 0.41 & 0.009 & 0.22 & $\begin{array}{l}\text { Strong evidence for } \\
\text { samples without } \\
\text { DNA }\end{array}$ \\
\hline Pendills & 13 & 11 & 0.017 & 0.86 & 11.2 & $\begin{array}{l}\text { Insufficient technical } \\
\text { replication }\end{array}$ \\
\hline Naomikong & 11 & 10 & 0.01 & 0.91 & 10 & $\begin{array}{l}\text { Insufficient technical } \\
\text { replication }\end{array}$ \\
\hline Roxbury & 9 & 8 & 0.012 & 0.89 & 8 & $\begin{array}{l}\text { Insufficient technical } \\
\text { replication }\end{array}$ \\
\hline Tahquamenon & 37 & 8 & 0.40 & 0.009 & 0.33 & $\begin{array}{l}\text { Strong evidence for } \\
\text { samples without } \\
\text { DNA }\end{array}$ \\
\hline Cheboygan & 35 & 27 & 0.044 & 0.66 & 23.1 & $\begin{array}{l}\text { Insufficient technical } \\
\text { replication }\end{array}$ \\
\hline Trout & 19 & 18 & 0.012 & 0.9 & 17.1 & $\begin{array}{l}\text { Insufficient technical } \\
\text { replication }\end{array}$ \\
\hline Devils River & 5 & 4 & 0.022 & 0.82 & 4.1 & $\begin{array}{l}\text { Insufficient technical } \\
\text { replication }\end{array}$ \\
\hline Fox River & 48 & 47 & 0.0023 & 0.98 & 47 & $\begin{array}{l}\text { Insufficient technical } \\
\text { replication }\end{array}$ \\
\hline Twin River & 35 & 34 & 0.0032 & 0.97 & 34 & $\begin{array}{l}\text { Insufficient technical } \\
\text { replication }\end{array}$ \\
\hline Escanaba & 33 & 30 & 0.01 & 0.91 & 30 & $\begin{array}{l}\text { Insufficient technical } \\
\text { replication }\end{array}$ \\
\hline Sturgeon Bay & 44 & 43 & 0.0025 & 0.98 & 43.1 & $\begin{array}{l}\text { Insufficient technical } \\
\text { replication }\end{array}$ \\
\hline Calumet & 29 & 20 & 0.08 & 0.47 & 13.6 & $\begin{array}{l}\text { Evidence for some } \\
\text { samples absent of } \\
\text { DNA }\end{array}$ \\
\hline
\end{tabular}

speculative extrapolation based on the best available data and should not be interpreted as quantitative empirical detection sensitivity.

\section{References}

Abell R, Olson DM, Dinerstein E, Hurley P, Diggs JT, Eichbaum W, Walters S, Wettengel W, Allnutt T, Loucks CJ, Hedao P, Taylor C (2000) Freshwater ecoregions of North America: a conservation assessment. Island Press, Washington, DC

Adebayo AA, Zhan A, Bailey SA, MacIsaac HJ (2014) Domestic ships as a potential pathway of nonindigenous species from the Saint Lawrence River to the Great Lakes. Biol Invasions 16:793-801
Apfalter P, Reischl U, Hammerschlag MR (2005) In-house nucleic acid amplification assays in research: how much quality control is needed before one can rely upon the results? J Clin Microbiol 43:5835-5841

Barnes MA, Turner CR, Jerde CL, Renshaw MA, Chadderton WL, Lodge DM (2014) Environmental conditions influence eDNA persistence in aquatic systems. Environ Sci Technol 48:1819-1827

Beja-Pereira A, Oliveira R, Alves PC, Schwartz MK, Luikart G (2009) Advancing ecological understandings through technological transformations in noninvasive genetics. Mol Ecol Resour 9:1279-1301

Biggs J, Ewald N, Valentini A, Gaboriaud C, Dejean T, Griffiths RA et al (2015) Using eDNA to develop a national citizen science-based monitoring programme for the great crested newt (Triturus cristatus). Biol Conserv 183:19-28 
Bott NJ, Ophel-Keller KM, Sierp MP, Rowling KP, McKay AC, Loo MG, Tanner JE, Deveney MR (2010) Toward routine, DNA-based detection methods for marine pests. Biotechnol Adv 28:706-714

Bowen AK, Goehle MA (2012) Surveillance for ruffe in the Great Lakes. U.S. Fish \& Wildlife Service station report. Fish and Wildlife Conservation Office, Alpena, MI, $42 \mathrm{p}$

Bowen AK, Keppner S (2013) Surveillance for ruffe in the Great Lakes. U.S. Fish \& Wildlife Service station report. Fish and Wildlife Conservation Office, Alpena, MI, $46 \mathrm{p}$

Bronte CR, Evrard LM, Brown WP, Mayo KR, Edwards AJ (1998) Fish community changes in the St. Louis River Estuary, Lake Superior, 1989-1996: is it Ruffe or population dynamics? J Gt Lakes Res 24:309-318

Busiahn TR (1997) Ruffe control: a case study of an aquatic nuisance species control program. In: D'Itri FM (ed) Zebra mussels and aquatic nuisance species. CRC Press, Boca Raton, pp 69-86

Crooks JA (2005) Lag times and exotic species: the ecology and management of biological invasions in slow-motion. Ecoscience 12:316-329

Darling JA (2014) Genetic studies of aquatic biological invasions: closing the gap between research and management. Biol Invasions 17:951-971

Darling JA, Mahon AR (2011) From molecules to management: adopting DNA-based methods for monitoring biological invasions in aquatic environments. Environ Res 111:978-988

Dejean T, Valentini A, Miquel C, Taberlet P, Bellemain E, Miaud C (2012) Improved detection of an alien invasive species through environmental DNA barcoding: the example of the American bullfrog Lithobates catesbeianus. J Appl Ecol 49:953-959

Duitama J, Kumar DM, Hemphill E, Khan M, Mandoiu II, Nelson CE (2009) PrimerHunter: a primer design tool PCR-based virus subtype identification. Nucleic Acids Res 37:2483-2492

Edsall TA, Selgeby JH, DeSorcie TJ, French JRP III (1993) Growth-temperature relation for young-of-the-year Ruffe. J Gt Lakes Res 19:630-633

Ficetola GF, Pansu J, Bonin A, Coissac E, Giguet-Covex C, De Barba $M$ et al (2015) Replication levels, false presences and the estimation of the presence/absence from eDNA metabarcoding data. Mol Ecol Resour 15:543-546

Finnoff D, Shogren JF, Leung B, Lodge DM (2007) Take a risk: preferring prevention over control of biological invaders. Ecol Econ 62:216-222

Fremling CR, Rasmussen JL, Sparks RE, Cobb SP, Bryan CF, Claflin TO (1989) Mississippi River fisheries: a case history. In: Dodge DP (ed) Proceedings of the International Large River Syposium (LARS). Canadian Special Publication of Fisheries and Aquatic Sciences 106, pp 309-351. Department of Fisheries and Oceans, Ottawa

Fullerton AH, Lamberti GA (2005) A comparison of habitat use and habitat-specific feeding efficiency by Eurasian Ruffe (Gymnocephalus cernuus) and yellow perch (Perca flavescens). Ecol Freshw Fish 15:1-9

Furlan EM, Gleeson D, Hardy CM, Duncan RP (2015) A framework for estimating the sensitivity of eDNA surveys. Mol Ecol Resour. doi:10.1111/1755-0998.12483
Goldberg CS, Pilliod DS, Arkle RS, Waits LP (2011) Molecular detection of vertebrates in stream water: a demonstration using Rocky Mountain tailed frogs and Idaho giant salamanders. PLoS ONE 6(7):e22746

Gunderson JL, Klepinger MR, Bronte CR, Marsden JE (1998) Overview of the international symposium on Eurasian ruffe (Gymnocephalus cernuus) biology, impacts, and control. J Gt Lakes Res 24:165-169

Jane SF (2014) An assessment of environmental DNA as a tool to detect fish species in headwater streams. Master's Thesis, University of Massachusetts

Jerde CL, Mahon AR (2015) Improving confidence in environmental DNA species detection. Mol Ecol Resour 15:461-463

Jerde CL, Lodge DM, Mahon AR, Chadderton WL, Barnes MA, McNulty J (2010) Final report: aquatic invasive species risk assessment for the Chicago sanitary and ship canal. In: Report to the United States Army Corps of Engineers, Environmental Laboratories, Cooperative Environmental Studies Unit, Vicksburg

Jerde CL, Mahon AR, Chadderton WL, Lodge DM (2011) Sight-unseen, detection of rare aquatic species using environmental DNA. Conserv Lett 4:150-157

Keller RP, Drake JM, Drew MB, Lodge DM (2011) Linking environmental conditions and ship movements to estimate invasive species transport across the global shipping network. Divers Distrib 17:93-102

Leigh P (1998) Benefits and costs of the Ruffe control program for the Great Lakes fishery. J Gt Lakes Res 24:351-360

Lodge DM, Williams S, MacIsaac HJ, Hayes KR, Leung B, Reichard S, Mack RN, Moyle PB, Smith M, Andow DA, Carlton JT, McMichael A (2006) Biological invasions: recommendations for US policy and managament. Ecol Appl 16:2035-2054

Lodge DM, Deines A, Gherardi F, Yeo DCJ, Arcella T, Baldridge AK, Barnes MA, Chadderton WL, Feder JL, Gantz CA, Howard GW, Jerde CL, Peters BW, Peters JA, Sargent LW, Turner CR, Wittmann ME, Zeng Y (2012) Global introductions of crayfishes: evaluating impact of species invasions on ecosystem services. Annu Rev Ecol Evol Syst 43:449-472

Mahon AR, Rohly A, Budny ML, Jerde CL, Chadderton WL, Lodge DM (2010) Environmental DNA monitoring and surveillance: standard operating procedures. In: Report to the United States Army Corps of Engineers, Environmental Laboratories, Cooperative Environmental Studies Unit, CESU agreement, Vicksburg

Margules CR, Pressey RL (2000) Systematic conservation planning. Nature 405:243-253

Mehta SV, Haight RG, Homans FR, Polasky S, Venette RC (2007) Optimal detection and control strategies for invasive species management. Ecol Econ 61:237-245

Myers JH, Simberloff D, Kuris AM, Carey JR (2000) Eradication revisited: dealing with exotic species. TREE 15:316-320

Nathan LM, Simmons M, Wegleitner BJ, Jerde CL, Mahon AR (2014) Quantifying environmental DNA signals for aquatic invasive species across multiple detection platforms. Environ Sci Technol 48:12800-12806

National Ballast Information Clearinghouse (NBIC) (2014) NBIC online database. Smithsonian Environmental 
Research Center and United States Coast Guard. http:// invasions.si.edu/nbic/search.html. Accessed 11 June 2015

Ogle DH, Ray BA, Brown WP (2004) Diet of larval Ruffe (Gymnocephalus cernuus) in the St. Louis River Harbor, Lake Superior. J Gt Lakes Res 30:287-292

Pilliod DS, Goldberg CS, Arkle RS, Waits LP (2013) Estimating occupancy and abundance of stream amphibians using environmental DNA from filtered water samples. Can J Fish Aquat Sci 70:1123-1130

Pratt D (1988) Distribution and population status of the ruffe (Gymnocephalus cernua) in the St. Louis estuary and Lake Superior. Great Lakes Fishery Commission research completion report. Wisconsin Department of Natural Resources, Superior, WI, $11 \mathrm{p}$

Rees HC, Maddison BC, Middleditch DJ, Patmore JRM, Gough KC (2014) The detection of aquatic animal species using environmental DNA: a review of eDNA as a survey tool in ecology. J Appl Ecol. doi:10.111/1365-2664.12306

Sieracki JM, Bossenbroek JM, Chadderton WL (2014) A spatial modeling approach to predicting the secondary spread of invasive species due to ballast water discharge. PLOS ONE. doi:10.1371/journal.pone.0114217

Sierszen ME, Keough JR, Hagley CA (1996) Trophic analysis of Ruffe (Gymnocephalus cernuus) and White Perch (Morone americana) in a Lake Superior coastal food web, using stable isotope techniques. J Gt Lakes Res 22:436-443

Smith GR (1981) Late cenozoic freshwater fishes of North America. Annu Rev Ecol Syst 12:163-193

Stepien CA, Brown JE, Neilson ME, Tumeo MA (2005) Genetic diversity of invasive species in the Great Lakes versus their Eurasian source populations: insights for risk analysis. Risk Anal 25:1043-1060

Sweeney BW, Battle JM, Jackson JK, Dapkey T (2011) Can DNA barcodes of stream macroinvertebrates improve descriptions of community structure and water quality? J N Am Benthol Soc 30:195-216

Takahara T, Minamota T, Doi H (2013) Using environmental DNA to estimate the distribution of an invasive fish species in ponds. PLoS ONE 8:e56584
Tamura K, Peterson D, Peterson N, Stecher G, Nei M (2011) MEGA5: molecular evolutionary genetics analysis using maximum likelihood, evolutionary distance, and maximum parsimony methods. Mol Biol Evol 28:2731-2739

Thomsen PF, Kielgast J, Lonsmann Iversen L, Moller PR, Rasmussen M, Willerslev E (2012a) Detection of a diverse marine fish fauna using environmental DNA from seawater samples. PLoS ONE 7:e41732

Thomsen PF, Kielgast J, Iversen LL, Wiuf C, Rasmussen M, Thomas M, Gilbert P, Orlando L, Willerslev E (2012b) Monitoring endangered freshwater biodiversity using environmental DNA. Mol Ecol 11:2565-2573

Turner CR (2015) Environmental DNA from aquatic macrobiota and its use in ecosystem monitoring. Dissertation, University of Notre Dame

Turner CR, Lodge DM, Xu CCY, Lamberti GA, Cooper MJ (2012) Evaluating environmental DNA detection alongside standard fish sampling in Great Lakes coastal wetland monitoring (Final Report to Illinois-Indiana Sea Grant)

Turner CR, Barnes MA, Xu CC, Jones SE, Jerde CL, Lodge DM (2014a) Particle size distribution and optimal capture of aqueous macrobial eDNA. Methods Ecol Evol 5:676-684

Turner CR, Miller DJ, Coyne KJ, Corush J (2014b) Improved methods for capture, extraction, and quantitative assay of environmental DNA from Asian Bigheaded Carp (Hypophthalmichthys spp.). PLoS ONE. doi:10.1371/journal. pone.0114329

United States Army Corps of Engineers (2014) The GLMRIS Report: Great Lakes and Mississippi river interbasin study. Washington DC, $232 \mathrm{p}$

Valentini A, Taberlet P, Miaud C, Civade R, Herder J, Thomsen $\mathrm{PF}$ et al (2015) Next-generation monitoring of aquatic biodiversity using environmental DNA metabarcoding. Mol Ecol. doi:10.1111/mec/13428

Wilcox TM, McKelvey KS, Young MK, Jane SF, Lowe WH, Whiteley WR, Schwartz MK (2013) Robust detection of rare species using environmental DNA: the importance of primer specificity. PLoS ONE 8:e59520 